\title{
FOREIGN DIRECT INVESTMENT DYNAMICS IN SOUTH AFRICA: REFORMS, TRENDS AND CHALLENGES
}

\author{
Mercy T. Musakwa* \\ University of South African, Pretoria, South Africa, e-mail: tsile.musa@gmail.com \\ Nicholas M. Odhiambo \\ University of South Africa, Pretoria, South Africa, e-mail: odhiamn@unisa.ac.za
}

(Received: February 2019; Accepted: April 2019; Published: June 2019)

\begin{abstract}
This paper gives an overview of foreign direct investment (FDI) in South Africa from 1980 to 2017. It highlights trends in FDI inflows, reforms that have been implemented to date, and challenges that need to be addressed in order to increase the FDI inflows into the country. Government reforms on FDI have been two pronged. Firstly, there are policies that are aimed at creating a strong competitive industry and a strong industrial base for investment. Among such policies are trade liberalisation policies, multilateral and regional integration policies, supportive industrial policies, and bilateral trade agreements. Secondly, there are policies that directly target the FDI investment. These policies include, amongst others, investment incentives, regulatory reforms, exchange control relaxation, and Bilateral Investment Treaties (BITs) reforms. The findings from this study show that FDI inflows have increased significantly from 1990 although they still remain depressed.
\end{abstract}

Keywords: South Africa; Foreign Direct Investment (FDI); FDI Inflows; Poverty

JEL Codes: F21

\section{Introduction}

Foreign direct investment (FDI) plays a crucial role in countries that have a low domestic savings rate like South Africa, by increasing the stock of capital formation for investment. FDI also has other positive direct effects such as creation of job opportunities that benefit the locals. FDI also brings technology which is important in increasing efficiency in production, competitiveness of the economy and quickening of the host country's economic integration into the global world. This makes FDI important to South Africa as a source of growth needed for the

*Corresponding author: Mercy T. Musakwa.E-mail: tsile.musa@gmail.com

Copyright (C) 2019 The Author(s). Published by VGWU Press

This is an Open Access article distributed under the terms of the Creative Commons Attribution License - Non Commercial - NoDerivs License (http://creativecommons.org/licenses/by-nc-nd/3.0/) which permits unrestricted

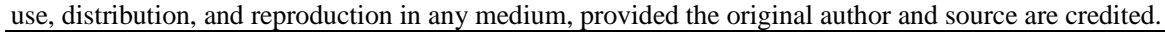


Musakwa, M.T., Odhiambo, N.M., (2019)

Foreign Direct Investment Dynamics in South Africa: Reforms, Trends and Challenges

achievement of other developmental goals such as poverty reduction, industrial development and provision of basic services.

Foreign direct investment has positive effects on the economy through boosting economic growth and alleviating poverty among other policy advancements. For instance, Esso (2010), in a study on the relationship between FDI and economic growth between 1970 and 2007 in Sub-Sahara Africa, confirmed a positive long run relationship. Feeny (2014) in a study on the Pacific Island countries from 1971 to 2010 found FDI to be associated with high growth. On the poverty front, there are empirical studies that support a negative relationship between FDI and poverty. Zaman et al. (2012) in a study on Pakistan 1985 to 2011 found FDI to reduce poverty. In the same vein, Gohou and Soumare (2012) in a study on African countries found a negative relationship between poverty and FDI. Thus, there is evidence of positive effects of FDI on economic growth and poverty alleviation.

The neoclassical and endogenous growth models cement the relationship between FDI and economic growth. In neoclassical growth theories technology and labour growth are exogenous. Increase in capital from domestic and foreign sources results in diminishing returns, which make FDI to have the same effect as domestic capital. The effect of FDI on growth in neoclassical theories is short term due to the diminishing returns. In the endogenous growth theories, technological progress is endogenous making FDI to have long-term effects on growth through offsetting diminishing returns. It is this relationship that makes foreign capital superior to domestic capital and important for economic growth especially if domestic sources are not sufficient to meet investment demands.

FDI in South Africa plays an important role in increasing the stock of capital for investment, helping in the creation of jobs for the locals and increasing technological transfer. The Government also gets revenue from taxes levied which is important in the provision of public services and support developmental programmes. High growth levels lead to an increase in job opportunities, general improvement in living standards and advancement in technology. Although FDI plays a pivotal role in economic growth and poverty alleviation, there is need to revisit the dynamics of the relationship in the context of changing global, regional and economic policies in South Africa. It is this lacuna that this paper would like to fill by putting FDI in South Africa in the spotlight.

The rest of the paper is organised as follows: Section 2 gives the literature review which is divided into two - an overview of FDI in South Africa and FDI reforms. Section 3 discusses the methodology and data employed in the study, while Section 4 outlines the results and Section 5 concludes the study.

34 Sciendo Studia Universitatis "Vasile Goldis" Arad. Economics Series Vol 29 Issue 2/2019 ISSN: 1584-2339; (online) ISSN: $2285-3065$

Web: publicatii.uvvg.ro/index.php/studiaeconomia. Pages $33-53$ 
Musakwa, M.T., Odhiambo, N.M., (2019)

Foreign Direct Investment Dynamics in South Africa: Reforms, Trends and Challenges

\section{Literature review}

\subsection{Foreign Direct Investment in South Africa: An Overview}

During the 1980s, the Government implemented policies that were inward looking because of isolation from the international community (Hanival and Maia, 2008). The imposition of sanctions and debt standoff in 1985 resulted in low FDI inflows (Cross, 2003). After gaining independence, the Government recognised the importance of integrating the economy into the global world and thus the Government was faced with the huge task of increasing investment.

Faced with low savings to boost the much needed economic growth and development the Government committed itself to attracting FDI to supplement domestic savings. This commitment was engraved in the economic plans pursued starting with the Reconstruction and Development Programme of 1994; the Growth, Employment and Redistribution Plan of 1996; the Accelerated and Shared Growth Initiative for South Africa of 2006; the New Growth Path of 2010 and the National Development Plan 2030. The overarching objective in all the policy plans was the realisation of economic development through the harnessing of domestic and foreign resources and thus social development advanced through poverty reduction; wealth redistribution and job creation.

Government policies pursued were geared at indirectly attracting FDI through building a vibrant, competitive and attractive industry for investment and direct policy interventions targeting foreign direct investment. Policies in support a conducive investment environment were pursued through sound industrial policy; support of competitive industry; bilateral and multilateral investment aimed at increasing market access of South African goods; regional integration initiative; trade liberalisation; and the creation of Special Economic Zones. Direct intervention reforms include: reduction in start-up costs include; targeted investment incentive on FDI such as 12I Tax incentive and incentives under Export Marketing and Investment Assurance Scheme (EMIA); investment support by Trade and Investment South Africa; production of a comprehensive Investor's Handbook for information provision to prospective investors; regulatory reforms through amendment of the Company Act, Competition Act, Property Right Related Acts; capital account liberalisation and the Promotion and Protection of Investment Bill.

The policy reforms resulted in a gradual increase in FDI flows into South Africa. FDI inflows as a percentage of GDP were depressed between 1980 and 1994. The inflow took an upward trend from 1994 and at the same time government was implementing major policy reforms. FDI inflows increased gradually from 1994, although the period was characterised by high peaks followed by steep declines (World Bank, 2019). The years with the highest FDI inflows were 2001, 2005 and 
Musakwa, M.T., Odhiambo, N.M., (2019)

Foreign Direct Investment Dynamics in South Africa: Reforms, Trends and Challenges

2008 with $6 \%, 2.5 \%$ and $3.4 \%$ respectively. The average share of FDI to GDP between 1994 and 2017 was 1.4\% (World Bank, 2019). South Africa received an average of 6\% FDI inflows in greenfields during the same period (UNCTAD, 2019). The percentage of South Africa greenfields FDI inflows to Africa greenfields inflows also recorded high fluctuation but an upward trend was registered (UNCTAD, 2019). The average share of South Africa FDI to FDI inflows to Africa in greenfields, from 2003 to 2017, was 6\% (UNCTAD, 2019).

Although FDI inflows improved from 1994 to 2017, South Africa faces a number of challenges that have retarded the inflows of FDI. These challenges include low economic growth, restrictive labour policies, misaligned BITs with socio-economic dynamics; shortage of skills; restrictive labour policies and burdensome regulatory and administrative requirements.

\subsection{Foreign Direct Investment Reforms in South Africa}

The policy reforms that were taken in South Africa were broad and the thrust was on direct policy interventions to harness FDI and the creation of a conducive industrial environment that supported new and established investments. A number of policy initiatives were undertaken to harness FDI. The Government took a gradual approach on the liberalisation of the trade and capital account to boost investment from domestic and foreign sources. This approach gave time for domestic agents and the economy to adjust to the liberalisation and a smooth transition has been realised (Hviding, 2006). The gradual approach ensured that the economic capacity was able to withstand shocks and competition arising from liberalisation.

In 1995 the financial rand was removed on non-residents but the ability to borrow and lend in foreign exchange was maintained. The financial rand was introduced in 1985. During the time the financial rand was in effect, all non-residents were obliged to deposit their proceeds from investments in the financial rand account (Hviding, 2006). The removal of the dual exchange rate was a positive step in attracting foreign investment.

The export surrender requirement period was adjusted upward from 1995. Initially export proceeds surrender period was 7 days and the period was gradually increased to 30 days in 1996 and to 180 days in 1998 (Hvding, 2006). The relaxation of the surrender period was a positive step for exporting companies and the general environment of operation which is an important factor for attracting new investment.

The Competition Act 89 of 1998 has undergone amendments to align its role to industry development. The act established a Competition Commission which is assigned the responsibility of investigating and controlling abuse of dominant positions and mergers. The act also makes a provision for the establishment of a

36 Sciendo Studia Universitatis "Vasile Goldis" Arad. Economics Series Vol 29 Issue 2/2019 ISSN: 1584-2339; (online) ISSN: $2285-3065$

Web: publicatii.uvvg.ro/index.php/studiaeconomia. Pages $33-53$ 
Musakwa, M.T., Odhiambo, N.M., (2019)

Foreign Direct Investment Dynamics in South Africa: Reforms, Trends and Challenges

Competition Tribunal and Competition Appeal Court that together make an important contribution to competition regulation. The act aims to address unjust practises that would prevent full participation in the economy of all South Africans (Competition Commission, 2015).

The Government took steps to advance trade liberalisation as a way of stimulating the country's participation in the global economy through trade. Prior to 1994, attempts to liberalise in the 1980 s were abandoned due to balance of payment pressure (Hviding, 2006). This resulted in restrictive policies aimed at minimising foreign currency outflow. Thus the trade policies that the Government inherited were restrictive with complex tariff structures. Policy changes were made to the trade regime to integrate the South African economy into the global economy.

Trade liberalisation that took place in the 1990s aimed at increasing trade. Trade liberalisation removed quantitative restriction and export subsidisation and replaced them with ad valorem tariff structures (Hviding, 2006). This resulted in the removal of quantitative restrictions by 1998 (Hviding, 2006). A gradual reduction in tariff rates and the removal of export subsidisation were introduced to improve trade. Government also entered or strengthened trade agreements with regional partners and international relations (Hviding, 2006).

South Africa introduced Industrial Development Zones (IDZ) in 2000 through the Manufacturing Development Act of 1993. The formation of IDZ was aimed at attracting foreign direct investment and export orientated industries especially in the manufacturing sector (Erasmus, 2011). Existing IDZ are East London, Coega, Richards Bay, Saidanha and Dube Tradeport. IDZ provided industrial space strategically located with great economic value. Investors wishing to operate a business in the IDZ obtain an operating permit from the Minister of Trade and Industry (Erasmus, 2011). A review of the IDZ showed a limitation that IDZ were located in areas adjacent to a sea port or an airport thus excluding other regions with industrial potential but that could not meet the criteria (DTI, 2012).

In 2001 the limit on outward investment was increased to R500 million and the amount was later revised to R1 million in 2003 (Hvding, 2006). All these reforms opened the South African economy to the international community. One of the objectives was gaining foreign capital that would increase capital stock for economic development, skills and technological spill over to local firms (National Treasury, 2011).

The industrial policies in South Africa support a vibrant and coherent policy framework aligned to broad economic growth agenda and create a clear space for new investment contribution. The National Industrial Policy Framework (NIPF) adopted in 2007 provided for a general framework for the Industrial Policy Action Plan (IPAP). The NIPF's thrust is on diversification of South African industry and less reliance on traditional commodities, thus building a knowledge based economy 
Musakwa, M.T., Odhiambo, N.M., (2019)

Foreign Direct Investment Dynamics in South Africa: Reforms, Trends and Challenges

and inclusive economic development. The first Industrial Policy Plan (IPAP) was published in 2007 and the current plan covers 2015/16 to 2017/18. The main objective of the IPAP is to support industry development and diversification to strengthen competitiveness and trade performance. The IPAP recognises the importance of manufacturing as a an engine for economic growth (DTI, 2015b).The policy framework focuses on building a diverse, strong and advanced industrial base that is competitive in the global economy. This would not only stimulate economic growth but also attract investors from the domestic and foreign markets.

The need to simplify and modernise the company registration process resulted in the Companies Act of 2008. The Companies Act of 2008 which became effective from 2011 provides for the registration of foreign companies to start a business in South Africa. The Companies Act also provides for amalgamations, mergers and takeovers of companies; rescue restrictions of financially distressed companies and the establishment of the Companies and Intellectual Property Commission and the Takeover Regulation Panel. Unlike the previous Act the 2008 Companies Act was written in simple language and was less prescriptive making it easy to understand (DTI, 2014/15b). Under the new act companies have the flexibility to change certain requirement depending on circumstances (DTI, 2014/15b).

In addition, other Acts that focus on property rights protection were passed. The Copyright Act of 1978 regulates and protects artist and computer programmes while the Intellectual Property Law Rationalisation Act of 1996 protects intellectual proprieties along with the intellectual Property Laws Amendment Act of 2013 which focuses on protecting indigenous knowledge. These Acts provide a legislative framework and place great importance on protecting property rights in South African business operations.

The relaxation of exchange control resulted in no restrictions on inflows and outflow of capital on foreign nationals by 2009 (National Treasury, 2011). There are no exchange controls imposed on non-residents except in cases where a nonresident enters into a transaction with a resident in South Africa (DTI, 2014/15b). Foreign investors have no restrictions on acquiring businesses in South Africa and dividends are freely remitted as long as the businesses remain financially sound (DTI, 2014/15b).However, interest payment for foreign loans is subject to exchange controls (DTI, 2014/15b).

In 2009 , the requirement of foreign companies to raise not more than $300 \%$ of foreign capital in the domestic market with prior approval from the South Africa Reserve Bank was removed (National Treasury, 2011). South African companies with a 75\% non-resident interest can access normal credit and financial assistance without a limit (DTI, 2014/15b). Restrictions are imposed on acquisitions of residential properties (DTI, 2014/15b).

38 Sciendo Studia Universitatis "Vasile Goldis" Arad. Economics Series Vol 29 Issue 2/2019 ISSN: 1584-2339; (online) ISSN: 2285 - 3065

Web: publicatii.uvvg.ro/index.php/studiaeconomia. Pages $33-53$ 
Musakwa, M.T., Odhiambo, N.M., (2019)

Foreign Direct Investment Dynamics in South Africa: Reforms, Trends and Challenges

The Government entered into a number of bilateral investment treaties (BITs) to stimulate investment after independence. These agreements were negotiated to protect outward FDI and provide a framework for inward foreign direct investment. Agreements in access of 40 were entered during 1994 to 2009, but more than half of the agreements are not in force (UNCTAD, 2015). A review of BITs was initiated in 2005 resulting in the DTI compiling a report reflecting areas that the country had to revise to come up with BITs agreements that are fashioned in line with domestic policy and constitutional obligations (DTI, 2009). Expropriation, protection and dispute resolution among other provisions of BITs have necessitated government review of BIT agreements (DTI, 2009). A lack of skills and a broad knowledge on BITs have been attributed to poor negotiation of BITs entered into by South Africa in the past (DTI, 2009). This has led to a policy shift favouring the termination of BITs that fall due for renewal with a view of renegotiating the BITs on new balanced terms (UCTAD, 2015).

Government regional integration commitment resulted in South Africa joining the Southern Africa Development Community (SADC), the African Union (AU), the Southern Africa Customs Union (SACU) and the Tripartite Free Trade Area (TFTA) consisting of Common Market for Eastern and Southern Africa (COMESA), the East African Community (EAC) and the SADC.

South Africa was a member of the SACU that consisted of South Africa, Swaziland, Botswana, Namibia and Lesotho from 1910 and part of the renewed agreement in 1969 (SACU, 2015). Upon gaining independence the Government was part of the negotiation for renewed custom union with the objective of aligning the customs union to new developments in trade relations (SACU, 2015). Another agreement was signed in 2002 to further trade relations among the member states. In the SACU goods from member countries enjoy tariff free trade, while a common external excise tariff is charged to non-members.

In 1994 South Africa joined the SADC as part of the regional integration initiative. In 2005 the SADC Protocol on Trade was signed and the main objective of the protocol was expending intra-regional trade; enhancing economic development and foreign investment in the region (SADC, 2015b). South Africa joined the AU in 1994 and contributed to the establishment of the AU Peace and Security Council. One of the objectives of the African Union is to facilitate socio-economic integration; promote stability and harmonisation of policies among existing and future regional communities (AU, 2015). South Africa adopted the New Partnership for Africa's Development (NEPAD) as a broad social transformation for Africa.

NEPAD was launched in 2001 with, among other objectives, the objective of promotion of inter-regional trade (The Presidency, 2015c). South Africa is also part of the NEPAD Presidential Information Championing Initiative with the goal of 
Musakwa, M.T., Odhiambo, N.M., (2019)

Foreign Direct Investment Dynamics in South Africa: Reforms, Trends and Challenges

putting up infrastructure like roads, rail, postal, energy and water. This strengthens South Africa's voice in the international community in areas that are affecting Africa and also in some areas that South Africa cannot achieve alone (Department of International Relations and Cooperation, 2015).

Another regional integration initiative was the Tripartite Free Trade Area (TFTA) consisting of Common Market for Eastern and Southern Africa (COMESA), East African Community (EAC) and SADC that was launched for negotiation in 2011 and concluded in June 2015 (EAC, 2015). The main objective of the TFTA is to deepen integration and harmonisation of policies on trade, customs and infrastructure between the three regional groupings (SADC, 2015a).

Assessment of FDI in South Africa is done on an individual basis (National Treasury, 2011). Mergers and acquisitions under the Competition Act of 1998 and Takeover Regulations Panel of 2008 are subjected to screening before approval (National Treasury, 2011). Depending on the size of the investment, approval is needed from the Competition Commission or Competition Tribunal for large mergers.

The DTI has taken on a number of initiatives to encourage greenfield and brownfield investment in the manufacturing sector. According to the DTI (2014/15a) greenfield are new projects that use new and unused industrial assets while brownfields are the expansion or upgrading of an existing project. The incentives have been grouped into clusters and those related to FDI under the Industrial Development category consist of Capital Projects Feasibility Programme; Critical Infrastructure Programme; Support Programme for Industrial Innovation and Manufacturing Competitiveness Enhancement Programme and Trade, Export and Investment Category with Export, Marketing and Investment Assistance; 12I Tax Allowance and Film and Television Production Incentive (DTI, 2014/15a).

The Export Marketing and Investment Assistance (EMIA) was launched in 1997 to develop the export market and attract FDI into South Africa (DTI, 2012/13). The most important objective of the EMIA, related to foreign investment, is the identification of new export markets while expanding existing ones to increase market access for South African goods (DTI, 2015c). Under the EMIA, National Pavilions at International level and International Trade Exhibition Assistance is offered. The EMIA is actively involved in research on FDI. Through outward selling and outward investment mission the scheme compensates exporters on expenses incurred in the process of harnessing FDI. Compensation ranges from airfares, transport of samples and subsistence allowance. Compensation is mainly for FDI in manufacturing and export oriented industries (DTI, 2015c).

The Critical Infrastructure Programme approved in 2000 aims to lower the cost of investment in critical infrastructure (DTI, 2012/13). The scheme offers a grant

40 Sciendo Studia Universitatis "Vasile Goldis" Arad. Economics Series Vol 29 Issue 2/2019 ISSN: 1584-2339; (online) ISSN: $2285-3065$

Web: publicatii.uvvg.ro/index.php/studiaeconomia. Pages $33-53$ 
Musakwa, M.T., Odhiambo, N.M., (2019)

Foreign Direct Investment Dynamics in South Africa: Reforms, Trends and Challenges

ranging from $10 \%$ to $30 \%$ of the total infrastructure cost to all registered legal entities in South Africa (DTI, 2014/15a). The Support Programme for Industrial Innovation was designed to encourage technology development by supporting financial assistance in the development stage. Once a prototype is produced the assistance ceases (DTI, 2014/15a).

In 2003 the Capital Projects Feasibility Programme was launched with a cost sharing between the firm and the Government for all feasibility studies leading to projects outside South Africa that would contribute to an increase in exports from local firms and market expansion (DTI, 2013/14). The main objective is to attract foreign investment (DTI, 2014/15a). The feasibility study should have been taken by an incorporated company in South Africa or partnership with a locally incorporated company in the case where feasibility is done by a foreign entity.

The Film and Television Production Incentive was launched in 2008 spanning to 2017 (DTI, 2013/14). Under the incentive structure is the Foreign Film and Television Production and Post-Production Incentives targeting foreign films (DTI, 2013/14). Qualifying companies should be foreign owned and the entity must be a Special Purpose Vehicle incorporated into South Africa for production of films. The main objective of the incentive is to attract foreign based films into South Africa (DTI, 2013/14).

In 2010 the 12I Tax Allowance Programme was launched and is on offer until 2017 (DTI, 2015a). This window is open to domestic and foreign investment projects and targets capital investment and training. On capital investment, the tax allowance given depends on the points that a project scores, which range from one to a maximum of eight. A project that scores 7 points or more is classified under preferred status and gets an investment allowance of R900 million if it is Greenfield or R550 million if it is Brownfield (DTI, 2015a). Low investment allowance is offered to projects that score less than 7 points (DTI, 2015a). An additional R36000 per each permanent employee is deductible from taxable income as an incentive for the training of employees. To date, the DTI has reported a total of 50 projects that have been supported with a rand value of 16 billion (DTI, 2015a).

In 2012 the Manufacturing Competitiveness Enhancement Programme under the Industrial Development umbrella was launched. The objective of the incentive is to support and upgrade production facilities, offer assistance to distressed companies and reduce the cost of working capital for exporting companies (DTI 2014/15a).

The DTI works in partnership with the Provincial Investment Promotion Agency (PIPAs). The PIPAs promote export and investment in line with the international relations and general government industrial policy. A Council of Trade and Industry Institutions (COTII) assists the DTI in a diverse policy issue in the delivery of its duties (DTI, 2015d). The members of the Council come from diverse 
Musakwa, M.T., Odhiambo, N.M., (2019)

Foreign Direct Investment Dynamics in South Africa: Reforms, Trends and Challenges

backgrounds that make its composition rich and capable of giving sound recommendations.

To align the IDZ with national economic policy dynamics, global environment and addressing the limitation of IDZ, Special Economic Zones (SEZ) were introduced. In 2014 the SEZ Act was passed. The SEZ Act of 2014 provides for the designation; operation and management of SEZ and the establishment of the SEZ Advisory Board which regulates and supervises SEZ permits. A fund was also established to support developmental projects within the SEZ. The purpose of the SEZ is to provide a clear predictable investment framework, and expand support services beyond infrastructure (DTI, 2015b). SEZ offers incentives like the IDZ although these have been expanded (DTI, 2015b). Incentives offered include preferential corporate tax of a $15 \%$, building allowance, employment and training, the 121 Tax Allowance aimed at supporting greenfield FDI and brownfield FDI. The DTI is in the process of establishing a one-stop-shop for SEZ. The one-stop shop will facilitate investor access to permits by reducing the steps needed in the approval process by exercising parallel approval; provide aftercare to existing businesses; help in planning, financing and environmental compliance (DTI, 2015b).

In 2016, Trade Invest Africa was launched to spearhead South Africa's economic strategy for Africa (DTI, 2018). Trade Invest Africa was formed to foster relationship between South African government and the private sector, with the objective of facilitating exports (DTI, 2018). Three main focus areas of Trade Invest Africa are to: (i) facilitate access to capital; (ii) assist with access to markets; and (iii) provide other non-financial support (DTI, 2018).

In an effort to enhance investor experience, a national one-stop-shop was launched as a single point of contact for investors (DTI, 2019). In addition, provincial branches of one-stop-shop were initiated for KwaZulu Natal, Western Cape and Gauteng Provinces (DTI, 2019). The formation of one-stop-shop will not only ease the administrative burden on investors but also provide vital information for investors (DTI, 2019).

South Africa has been using the Constitutional provisions and the Expropriation Act of 1975 to protect property (Centre for Development and Enterprise, 2019). In 2018 there was consensus to amend the constitution and repeal the 1975 Expropriation Act to take a new dimension in property where a possibility of expropriation is accommodated (Centre for Development and Enterprise, 2019). This resulted in the Expropriation Bill of 2018 being gazetted for comments. The move by the government to allow instances where land is expropriated without compensation has negatively affected investment, especially in agricultural sector and its upstream and downstream sectors according to Bashoff et al. (2018).

42 Sciendo Studia Universitatis "Vasile Goldis" Arad. Economics Series Vol 29 Issue 2/2019 ISSN: 1584-2339; (online) ISSN: $2285-3065$

Web: publicatii.uvvg.ro/index.php/studiaeconomia. Pages $33-53$ 
Musakwa, M.T., Odhiambo, N.M., (2019)

Foreign Direct Investment Dynamics in South Africa: Reforms, Trends and Challenges

\section{Methodology and empirical data}

This study is based on a desk top review of policy documents from various government sources and international sources on the policies which have been reigned by the South African government, aligned to promoting foreign direct investment flows. Among such policy documents were policy documents that focused on direct interventions to promote FDI inflows and those that focused on indirect FDI support through creating a lucrative environment for foreign investment.

In support of the policy review, statistics are drawn from different data bases to show the trends in FDI. Foreign direct investment and gross domestic investment figures are obtained from World Bank development indicators. Greenfield and FDI inflows as a percentage of FDI inflows are extracted from Organisation for Economic Co-operation and Development (OECD) data base. Further, in an effort to position South Africa in relation to its trade partners; Brazil, Russia, India, China and South Africa (BRICS) FDI inflows were extracted from OECD. The FDI's response to a myriad of FDI policies implemented is reflected in FDI inflows and the associated discussions. Also discussed are the challenges that South Africa still has to content with in the initiative to improve FDI inflows.

\section{Empirical results}

The results and discussion on FDI policy reforms are divided into two. Firstly, the trends in FDI inflows are discussed followed by a brief comparison of FDI inflows with other BRICS countries. Secondly, a discussion is provided with more emphasises on the challenges that South Africa has to content with in the fight to promote FDI inflows into the country.

\subsection{Foreign Direct Investment Trends in South Africa}

In response to the policies that the South African government rolled out in support of FDI inflows, FDI inflows into South Africa remained depressed from 1980 to 1994. FDI inflows increased gradually from 1994, although the period was characterised by huge fluctuations. Figure 1 shows FDI inflows as a percentage of Gross Domestic Product (GDP) from 1980-2017. 


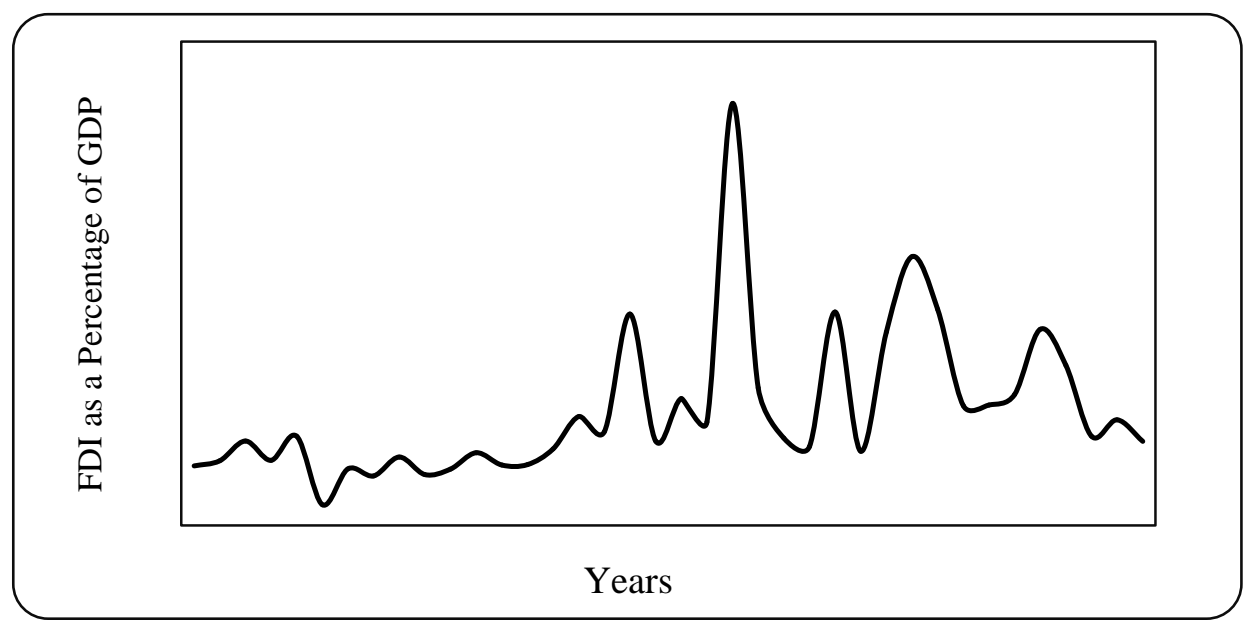

Figure 1. Trends in Foreign Direct Investment Inflows as a Percentage of GDP (1980-2017)

Source: World Bank (2019)

FDI inflows as a proportion of GDP were thin between 1980 and 1994 as shown in Figure 1. The average percentage between 1980 and 1994 was $0.03 \%$ (World Bank, 2019). In 1980 a negative $0.012 \%$ was registered before an increase of 0.09\% in 1981 (World Bank, 2019). The period between 1980 and 1984 recorded a positive share of FDI to GDP with an average percentage of $0.2 \%$ (World Bank, 2019). Negative inflows were recorded from 1986 to 1990, with the exception of 1988 (World Bank, 2019). The average percentage for the period, 1991 to 2017 was $1.3 \%$, while for the period, 1994 to 2017 was $1.4 \%$ (World Bank, 2019). The years that recorded high inflows were 2001, 2008 and 2009, with 5.9\%, 3.4\% and $2.5 \%$ respectively, while the years that recorded the lowest between 1994 and 2017 were 1994, 2004 and 2006, with $0.26 \%, 0.3 \%$ and $0.2 \%$ respectively (World Bank, 2019). Thus after independence FDI inflows did increase in response to government policy reforms.

FDI is important in closing the domestic investment gap. Given the low saving rate in South Africa, that limits investment capital, FDI plays an important role in boosting economic growth. Figure 2 shows FDI inflows as a share of Gross Fixed Capital Formation (GFCF). 
Musakwa, M.T., Odhiambo, N.M., (2019)

Foreign Direct Investment Dynamics in South Africa: Reforms, Trends and Challenges

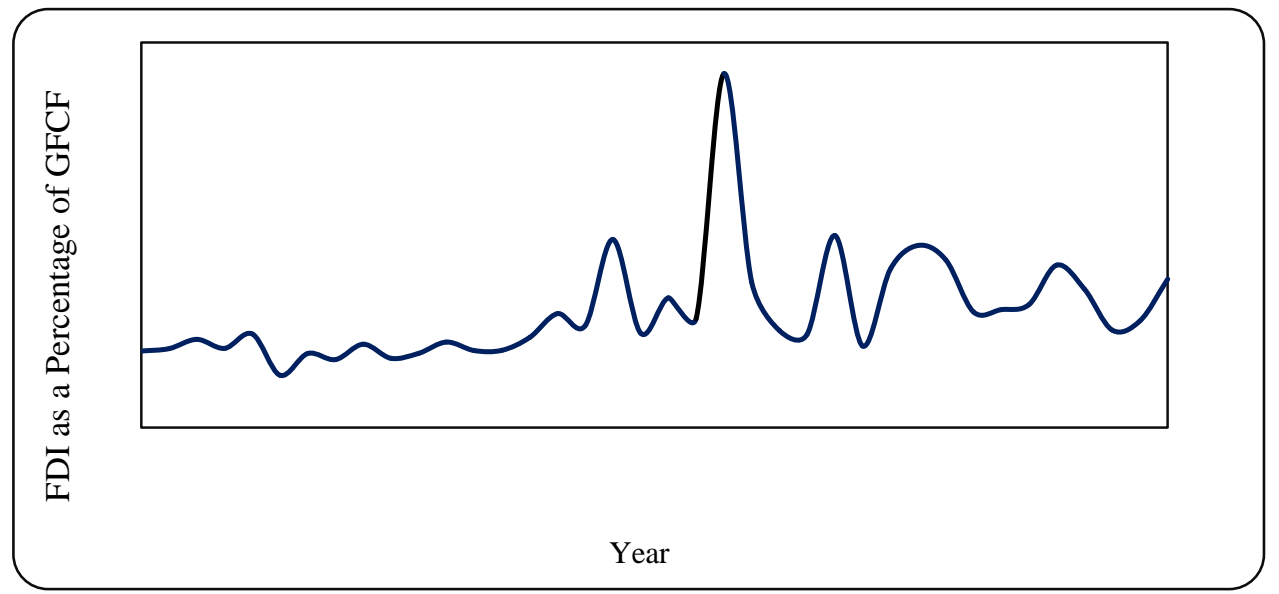

Figure 2. FDI as a Proportion of Gross Fixed Capital Formation (GECF) 1980-2017 Source: UNCTAD (2019)

The percentage of FDI to GFCF recorded high peaks, followed by sharp declines during the period from 1980 to 2017 (UNCTAD, 2019). In 1980 the percentage of FDI to GFCF was negative at $0.04 \%$ and remained depressed until 1993 when a positive $0.05 \%$ was recorded (UNCTAD, 2019). The percentage was low between 1991 and 1993, with an average percentage of 0.3\% (UNCTAD, 2019). Marked increases were registered from 1994 with $1.7 \%$, while the average percentage between 1994 and 2005 was 8.5\% (UNCTAD, 2019). The percentage of FDI to GFCF was exceptionally high in 1997 and again in 2001 with $14.4 \%$ and $35.9 \%$ respectively (UNCTAD, 2019). In 2006 the percentage of FDI to GDP dropped by $14 \%$, recording $0.6 \%$ (UNCTAD, 2019). The average percentage from 2007 to 2017 was $7.9 \%$ (UNCTAD, 2019). FDI as a percentage of GFCF was thus highly volatile, making its contributions unpredictable

Greenfields expand industry base by providing new backward and forward linkages and employment opportunities. Figure 3 shows trends in greenfield FDI inflows in South Africa and South Africa greenfield FDI inflows as a percentage of greenfield FDI inflows in Africa. 
Musakwa, M.T., Odhiambo, N.M., (2019)

Foreign Direct Investment Dynamics in South Africa: Reforms, Trends and Challenges

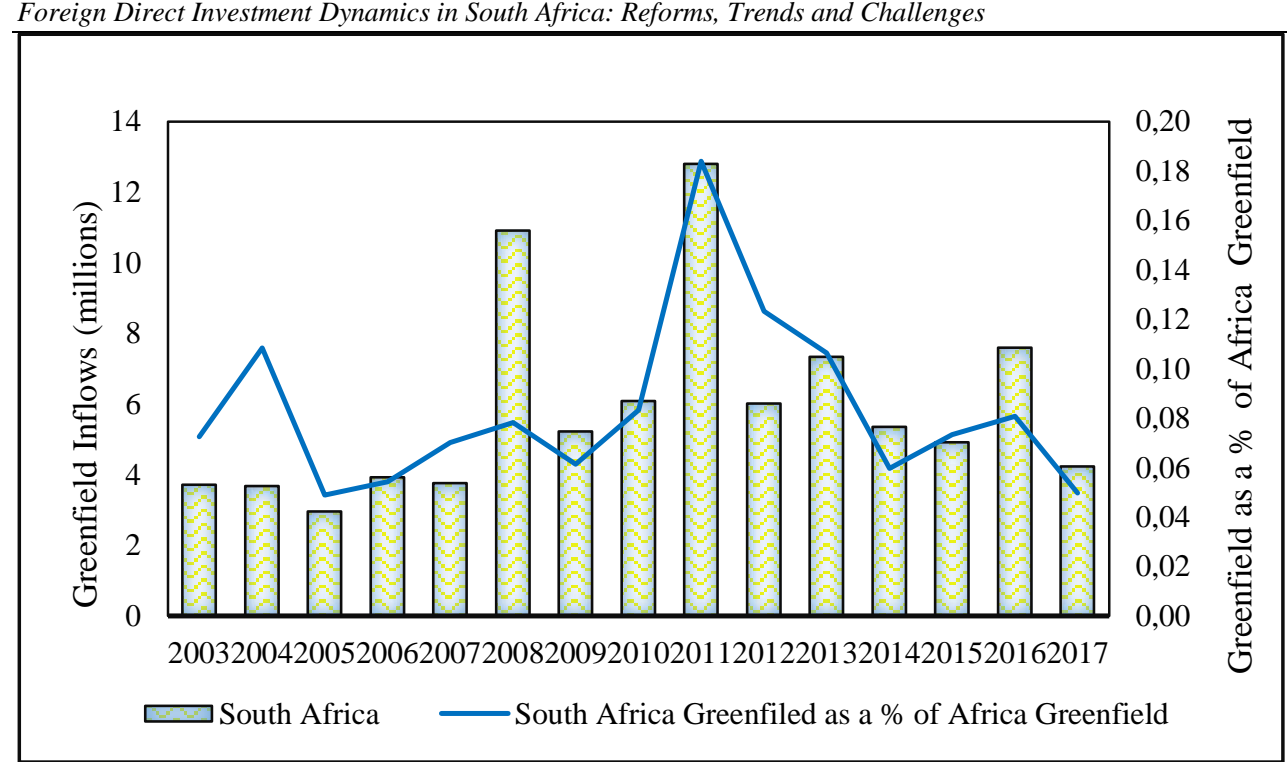

Figure 3. South Africa FDI inflows in Greenfields and as a Proportion of Africa Greenfields Inflows 2003 - 2017

Sources: UNCTAD (2019)

Figure 3 shows a decrease in greenfield FDI in South Africa from 2003 to 2005 with $\$ 3.7$ billion and \$3 billion recorded for 2003 and 2005 (UNCTAD, 2019). South Africa registered a fall in greenfield FDI from $\$ 4.4$ billion in 2003 to $\$ 3$ billion in 2005 (UNCTAD, 2019). An increase of $33 \%$ in greenfield FDI was realised from 2005 to 2006, reaching $\$ 4$ billion (UNCTAD, 2019). The improvement in greenfield FDI continued up to 2008 (UNCTAD, 2019). In 2008 greenfield FDI inflows reached $\$ 11$ billion (UNCTAD, 2019). However, the positive trend was short-lived when a drop of 52\% was recorded in 2009 and a marginal improvement of $16 \%$ in 2010 to record an inflow of $\$ 6$ billion (UNCTAD, 2019). In 2011 a recovery of $\$ 6.7$ billion was recorded (UNCTAD, 2019). Greenfied FDI inflows fluctuated between $\$ 7.5$ billion and $\$ 4.3$ billion from 2013 to 2017, registering an average of $\$ 5.9$ billion (UNCTAD, 2019).

South Africa's greenfields inflows as a percentage of greenfields inflows in Africa were at 7\% in 2003 and rose by $11 \%$ in 2004 (UNCTAD, 2019). The increase was not sustained in 2005 and a fall of $6 \%$ was recorded (UNCTAD, 2019). Consistent growth was recorded from 2005 to 2008, with an average of 6\% (UNCTAD, 2019). In 2010 the share of South Africa's greenfield FDI to Africa greenfield FDI dropped marginally from 6\% in 2009 to $8 \%$ (UNCTAD, 2019). The highest share of greenfield FDI to South Africa as a proportion of greenfield FDI inflow in

46 Sciendo Studia Universitatis "Vasile Goldis" Arad. Economics Series Vol 29 Issue 2/2019 ISSN: 1584-2339; (online) ISSN: 2285 - 3065

Web: publicatii.uvvg.ro/index.php/studiaeconomia. Pages $33-53$ 
Musakwa, M.T., Odhiambo, N.M., (2019)

Foreign Direct Investment Dynamics in South Africa: Reforms, Trends and Challenges

Africa was recorded in 2011 at 18\% (UNCTAD, 2019). The average greenfield FDI inflows in South Africa as a percentage of Africa greenfields inflows from 2013 to 2017 was 7\% (UNCTAD, 2019). Overall, South Africa greenfield FDI inflows remain depressed during the period under review.

FDI inflows in South Africa increased gradually from 2006 and 2009. Consistent increases in inflows were registered between 2011 and 2017. Table 1 shows trends in FDI inflows in South Africa in relation to other BRICS countries.

Table 1. Foreign Direct Investment Inflows in the BRICS Countries: 2006-2017

\begin{tabular}{|c|c|c|c|c|c|}
\hline Year & Brazil & South Africa & Russia & China & India \\
\hline 2006 & 18822 & 303 & 37442 & 124082 & 20029 \\
\hline 2007 & 34585 & 6764 & 54922 & 156249 & 25228 \\
\hline 2008 & 45058 & 8172 & 75856 & 171535 & 43406 \\
\hline 2009 & 25949 & 8614 & 27752 & 131057 & 35581 \\
\hline 2010 & 83747 & 4015 & 31668 & 243703 & 27397 \\
\hline 2011 & 96152 & 3785 & 36868 & 280072 & 36499 \\
\hline 2012 & 76098 & 44403 & 30188 & 241214 & 23996 \\
\hline 2013 & 53060 & 8296 & 53397 & 290928 & 28153 \\
\hline 2014 & 73086 & 5772 & 29152 & 268097 & 34576 \\
\hline 2015 & 64291 & 1729 & 11858 & 242489 & 44008 \\
\hline 2016 & 57935 & 2235 & 37176 & 174750 & 44458 \\
\hline 2017 & 62713 & 1325 & 25954 & 168224 & 39966 \\
\hline
\end{tabular}

Source: OECD 2019 (figures in USD millions)

South Africa experienced an increase in FDI inflows from $\$ 303$ million in 2006 to $\$ 6.7$ billion in 2007 and a further increase of $5.4 \%$ in 2009 , before declining to $\$ 4.0$ billion in 2010 (OECD, 2019). This compares unfavourably with other BRICS countries that had positive inflows in 2006, with Russia, China, India and Brazil receiving $\$ 37.4$ billion, $\$ 124.1$ billion, $\$ 20.3$ billion and $\$ 18.8$ billion respectively (OECD, 2019). In 2009 all countries were affected by the financial crisis with the exception of South Africa were an increase of $\$ 442$ million was registered (OECD, 2019). Russia recorded the highest contraction in 2009 in FDI of 63\%, while India registered a decrease of $22 \%$ (OECD, 2019). From 2009 South Africa recorded another fall of $\$ 4.6$ billion in 2010 (OECD, 2019). South Africa, as did Russia and China, registered consistent growth in FDI from 2011 to 2013 (OECD, 2019). The growth in FDI inflows between 2008 and 2017 for South Africa was a negative 83\% which was a high contraction in comparison to Brazil that registered a positive growth of $39 \%$, at the same period that China, India and Russian had contraction of $2 \%, 8 \%$ and $66 \%$ respectively (OECD, 2019). However, although 
Musakwa, M.T., Odhiambo, N.M., (2019)

Foreign Direct Investment Dynamics in South Africa: Reforms, Trends and Challenges

South Africa experienced a general increase in FDI inflows, the values remained very low in comparison to other BRICS countries.

\subsection{Challenges in Increasing Foreign Direct Investment in South Africa}

Although a lot has been done on FDI policy reforms, the South African government still has to contend with a number of challenges to realise consistent increases in FDI inflows. South Africa faces a challenge on Bilateral Investment Treaties which are not aligned with the constitution obligations (DTI, 2009). The BITs have been restrictive in the area of protection of investors and expropriation of property. The BITs dispute resolution is also carried out at international courts including cases that could be settled in South Africa Courts (DTI, 2009). South Africa had a number of litigations on appropriation of foreign investor property partly contributing to a review of the agreements with a view to aligning investment policy with government policy and the constitutional obligation (DTI, 2009). The DTI undertook a review of the BIT Policy Framework to establish areas that needed adjustment to suit the South African development agenda at the same time accommodating international best practice (DTI, 2009). This has culminated in the termination of some BTIs with some countries like Germany and the Netherlands (UNCTAD, 2015). The government has come up with a new framework for BITs guided by the Promotion and Protection of Investment Bill drafted in 2013.

Another challenge that the country faces is putting the economy on a high growth path that would increase business prospects and attract more investors from local and foreign spheres (IMF, 2004). The National Development Plan 2030 also noted the importance of high economic growth as important in achieving other objectives set in the plan (The Presidency, 2015a). High economic growth attracts foreign investors and provides a conducive environment for business operations. Gross Domestic Product (GDP) growth in South Africa increased from 1994 with a growth of $3.2 \%$ before taking a downturn from $5.6 \%$ in 2006 to $-1.5 \%$ in 2009 (UNCTAD, 2019). After the financial crisis the growth has been depressed, from $3 \%$ in 2010 to $1.3 \%$ in 2017 (UNCTAD, 2019).

The National Planning Commission in its Diagnostic Report highlighted inadequate and under maintained infrastructure as a challenge in the advancement in economic growth and development (The Presidency, 2011). The distance between South Africa and its trading partners also increases the need for an efficient transport network that reduces the cost of exports. This is worsened by Africa's poor infrastructure network (The Presidency, 2011). Poor infrastructure network negatively affects investor decisions to settle in South Africa. Infrastructure is an important factor that foreign investors consider when investing in a country (Borenstein et al., 1998).

48 Sciendo Studia Universitatis "Vasile Goldis" Arad. Economics Series Vol 29 Issue 2/2019 ISSN: 1584-2339; (online) ISSN: $2285-3065$

Web: publicatii.uvvg.ro/index.php/studiaeconomia. Pages $33-53$ 
Musakwa, M.T., Odhiambo, N.M., (2019)

Foreign Direct Investment Dynamics in South Africa: Reforms, Trends and Challenges

South Africa faces a challenge of skills shortage which is negatively affecting investment (The Presidency, 2015b). The Government has put in place programmes to develop skills of the workforce in South Africa with the Department of Labour championing the programmes. The Amended Skills Development Act of 2003 provides a framework for skills development. The purpose of the act is to develop skills in the workforce; increase investment levels in education and training; establish a National Skills Authority and National skills Fund; the establishment of the Sector Training and Education Authority and learnership agreements. South Africa has a large pool of unskilled labour which partly contributes to the high unemployment rate which stood at $24.3 \%$ in 2014 (South Africa Reserve Bank, 2015). This calls for more government initiatives.

Restrictive labour market policies in South Africa increase the cost of doing business in South Africa which negatively affects investment (The Presidency, 2011). Labour policies in South Africa are protective of the employees making firing cost high. The Government regulates the labour market to protect employees, support equity and general health and safety (Government Communication and Information System, 2010). A study carried out by IMF (2005) showed labour market rigidities are associated with high unemployment.

Burdensome administration and regulations of FDI are a challenge in South (National Treasury, 2011). Harmonisation of licensing, the authorisation process and sectorial regulations help to reduce administration costs on FDI (National Treasury, 2011). Systematic coordination of different departments that are in the approval process will also shorten the time to actual capital inflow. Reporting of foreign activities also needs to be coordinated to avoid duplication of information compliance by different departments. Regulations play an important role as a deterrent to bad business ethics and also as an incentive to foreign and domestic investment (Busse and Groizard, 2006).

\section{Conclusions}

The paper has given an overview of the FDI inflows into South Africa and has highlighted the reforms that have been implemented since the 1980s. The study has also discussed the results of the study divided into the trends in FDI and the challenges that South Africa still need to contend with to increase FDI inflows. The policies government availed focused on attracting FDI from two fronts. The first front focused on creating a conducive investment climate for investment with policies including trade liberalisation, exchange control relaxation; regional integration and industrial policy. The second policy thrust was a direct policy intervention on FDI and policies advanced in this category included capital account liberalisation; BITs reforms; regulation reforms and investment incentives. These reforms have resulted in a gradual increase in FDI inflows in South Africa. FDI 
Musakwa, M.T., Odhiambo, N.M., (2019)

Foreign Direct Investment Dynamics in South Africa: Reforms, Trends and Challenges

inflows as a percentage of GDP from 1980 to 1994 were low. Some years showed a negative percentage during the same period. FDI inflows improved from 1994 although the inflows were somewhat erratic in some instances. South Africa greenfield FDI inflows as a percentage of greenfield FDI inflow in Africa grew from 2003 to 2014 registering an average percentage of $8 \%$ over the period.

Despite the positive developments that have been recorded on FDI inflows in South Africa since 1994, a number of challenges still remain. These challenges include, amongst others, low economic growth, the need for harmonisation of FDI regulations and approvals, the need to align BITs with the current developmental needs, skills shortage, and restrictive labour policies. Based on the findings of this study, it is recommended that South African government continue to support policies that increase FDI inflows on one hand and create a good investment environment to attract FDI on the other hand. Further, policy makers in South Africa are recommended to reform restrictive labour policies, support skills development, strive to boost economic growth and increase the ease of doing business - in terms of administration and turnover time.

\section{Acknowledgements}

The authors thank the anonymous reviewers and editor for their valuable contribution.

\section{Funding}

The research received no funding from any funding agency.

\section{Author Contributions}

Dr M.T. Musakwa and Professor Nicholas Odhiambo conceived the study and worked together to design the study, review policy documents, analyse the data and interpret it.

\section{Disclosure Statement}

The authors do not have any competing professional or personal interests from other parties.

\section{References}

1. AU, (2015), AU in a Nutshell, [Online] Available from www.au.int, [Accessed 10 July 2015]

2. Bashoff, T., Sihlolo, W., and Ntombela, S., (2018), Redistribution of agricultural land: Expropriation without compensation, Debate, [Online] Available from https://agbiz.co.za, [Accessed 7 April 2019]

3. Borensztein, E., de Gregono, J., Lee, J., (1998), How does foreign direct investment affect economic growth? Journal of International Economics 45(1), pp. $115-135$

50 Sciendo Studia Universitatis "Vasile Goldis" Arad. Economics Series Vol 29 Issue 2/2019 ISSN: 1584-2339; (online) ISSN: $2285-3065$

Web: publicatii.uvvg.ro/index.php/studiaeconomia. Pages $33-53$ 
Musakwa, M.T., Odhiambo, N.M., (2019)

Foreign Direct Investment Dynamics in South Africa: Reforms, Trends and Challenges

4. Busse, M., Groizard, J.L., (2006), Foreign Direct Investment, Regulation and Growth, Policy Research Working Paper 3882, World Bank, Washington DC

5. Centre for Development and Enterprise, (2019), Land Expropriation Bill 2018, [Online] Available at www.cde.org.za, [Accessed 6 April 2019]

6. Competition Commission, (2015), Competition Act, [Online] Available from http://www.comcom.co.za, [Accessed 17 June 2015]

7. Cross, J.H., (2003), Global integration and capital account liberalization, [Online] Available from <http://www.bis.org>, [Accessed 15 April 2015]

8. Department of International Relations and Cooperation, (2015), African Union and NEPAD, [Online] Available from <http://www.dfa.gov.za> [Accessed 10 May 2015]

9. DTI, (2009), Bilateral Investment Treaty Policy Framework Review: Government Position Paper, [Online] Available from <pmg-asset.s3-website-euwest-1.amazonaws.com>, [Accesed 14 June 2015]

10. DTI, (2012), Policy on the Development of Special Economic Zones in South Africa, [Online] Available from www.thedti.gov.za, [Accessed on 14 June 2015]

11. DTI, (2012/13), The Incentive Development and Administration Performance Report, [Online] Available from http://www.dti.gov.za, [Accessed 10 July 2015]

12. DTI, (2013/14), The Incentive Development and Administration Performance Report, [Online] Available from http://www.dti.gov.za, [Accessed 8 July 2015]

13. DTI, (2014/15a), A Guide to dti Incentives Scheme, [Online] Available from http://www.dti.gov.za, [Accessed 8 July 2015]

14. DTI, (2014/15b), Investor Handbook, [Online] Available from http://www.dti.gov.za, [Accessed 8 July 2015]

15. DTI, (2015a), Financial Assistance and Tax Allowance, [Online] Available from http://www.thedti.gov.za, [Accessed 28 April 2015]

16. DTI, (2015b), Industrial Development, [Online] Available from http://www.dti.gov.za, [Accesed 16 June 2015]

17. DTI, (2015c), Export Marketing and Investment Assistance, [Online] Available from <http://www.dti.gov.za>, [Accessed 18 June 2015]

18. DTI, (2015d), DTI agencies, [Online] Available from <http://www.dti.gov.za〉. [Accessed 16 June 2015]

19. DTI, (2018), Special Economic Zone Advisory Board Annual Report 2017/2018, [Online] Available from www.dti.gov.za, [Accessed 1 April 2019]

20. DTI, (2019), Sector Opportunities, [Online] Available from $<$ https://www.thedti.gov.za, [Accessed 6 April 2019]

21. EAC, (2015), Agreement Establishing a Tripartite Free Trade among COMESA, EAC and SADC, [Online] Available from http://www.eac.int, [Accessed 10 July 2015] 
Musakwa, M.T., Odhiambo, N.M., (2019)

Foreign Direct Investment Dynamics in South Africa: Reforms, Trends and Challenges

22. Erasmus, A., (2011), Trade Zones: Recommendation for South Africa, Occasional Paper, South Africa Institute of International Affairs (SAIIA), [Online] Available from http://www.saiia.org.za, [Accessed 8 June 2015]

23. Esso, L.J. (2010), Long run relationship and causality between foreign direct investment and growth: Evidence from ten African countries, International Journal of Economics and Finance 2, pp. 168-177

24. Feeny, S., Iamsiraroj, S., McGillivray, M., (2014), Growth and foreign direct investment in the Pacific Island countries, Economic Modelling, 37, pp. 337-339

25. Gohou, G., Soumare, I., (2012), "Does foreign direct investment reduce poverty in Africa and are there regional differences?", World Development, 40(1): pp. $75-95$

26. Government Communication and Information System, (2010), New Growth Path, [Online] Available from http://www.gcis.gov.za, [Accessed 27 May 2015]

27. Hanival, S., Maia, J., (2008), An Overview of the Performance of the South African Economy since 1994, Paper Commissioned for the fifteen year review

28. Hviding, K., (2006), Liberalising trade and capital transaction: An overview, [Online] Available from http://www.imf.org/pubs/nft/2006/soafrica/eng/.../sach8. [Accessed 9 May 2015]

29. IMF, (2004), IMF Country Report: Selected Issues, Number 04/379

30. National Treasury, (2011), A Review Framework For Cross Border Direct Investment in South Africa, National Treasury, Discussion Paper

31. OECD, (2019), Country Profile Statistics, [Online] Available from <stats.oecd.org>, [Accessed 2 April 2019]

32. SACU, (2015), SACU Agreements, [Online] Available from http://www.sacu.int, [Accessed 15 July 2015]

33. SADC, (2015a), Tripartite Cooperation, [Online] Available from www.sadc.int, [Accessed 3 July 2015]

34. SADC, (2015b), Free Trade Area, [Online] Available from www.sadc.int, [Accessed 10 July 2015]

35. South Africa Reserve Bank, (2015), Quarterly Bulletin: March 2015, Number 275

36. The Presidency, (2011), The Diagnostic Report, [Online] Available from <htttp://www.nationalplanning.wordpress.com>, [Accessed 26 May 2015]

37. The Presidency, (2015a), National Development Plan 2030, [Online] Available from http://www.thepresindency.gov.za>, [Accessed 26 May 2015]

38. The Presidency, (2015b), Medium Term Strategic Framework 2014-19, [Online] Available from <http://www.poa.gov.za, [Accessed 12 June 2015]

39. The Presidency, (2015c), Twenty Year Review South Africa: 1994-2014, [Online] Available from http://www.poa.gov.za, [Accessed 7 June 2015]

52 Sciendo Studia Universitatis "Vasile Goldis" Arad. Economics Series Vol 29 Issue 2/2019 ISSN: 1584-2339; (online) ISSN: 2285 - 3065

Web: publicatii.uvvg.ro/index.php/studiaeconomia. Pages $33-53$ 
Musakwa, M.T., Odhiambo, N.M., (2019)

Foreign Direct Investment Dynamics in South Africa: Reforms, Trends and Challenges

40. UNCTAD, (2015), Bilateral Investment Treaties, [Online] Available from http://www.investmentpolicyhub.unctad.org, [Accessed 17 June 2015]

41. UNCTAD, (2019), UNCTADstat, [Online] Available from <http://unctadstat.unctad.org/EN/>, [Accessed 28 April 2019]

42. World Bank, (2019), Development Indicators, [Online], Available from <http:// www.data.worldbank.org>, [Accessed 30 April 2019]

43. Zaman, K., Khan, M.M., Ahmad, M., (2012), "The relationship between foreign direct investment and pro-poor growth policies in Pakistan: The new interface.” Economic Modelling, 29, pp. 1220-1227 